\title{
PROBLEMATIKA TINDAK PIDANA ITE DALAM PERSFEKTIF SISTEM HUKUM
}

\author{
Firmansyah \\ Fakultas Hukum \\ Universitas Muhammadiyah Parepare, Jalan Jenderal Ahmad Yani KM 6 Kota Parepare \\ Kode Pos 91113, Telpon : 0421-22757/Fax 0421-2554 Sulawesi Selatan Indonesia \\ Email: firmansyah.abdurrahman85@gmail.com
}

\begin{abstract}
Abstrack: Criminal Act of ITE or cyber crime is a new form of dimension of crime of the present which previously did not know, then the necessary tools to accommodate criminal acts committed in cyberspace, such as the Law related to it, this Journal aims to know the related Problems the problem of the crime of ITE as well as to know the efforts of handling ITE crime. This journal uses the normative juridical method. While the analysis with descriptive method kualitatif. The results of this paper Cybercrime problem is a very complex issue both related to legal issues, such as jurisdiction issues that are Problems related to power or authority, namely who is in charge of the internet world, Another issue is related to ethics and morals related to good and bad values and the steps taken in cyber crime is focused on the substance of regulatory issues namely the harmonization of rules of law in various countries, the problem of structures in which the state must be pro-active such as attending international forums related to cyber crime, giving training to the apparatus, and from legal culture is a paradigm shift related to Cyber crime as a criminal act.
\end{abstract}

Key Word: cyber crime, yurisdiction, problem

\begin{abstract}
Abstrak: Tindak Pidana ITE atau cyber crime merupakan Tindak merupakan salah satu bentuk dimensi baru dari kejahatan masa kini yang sebelumnya tidak kenal, maka diperlukan perangkat untuk mengakomodasi tindak pidana yang dilakukan didunia maya, semisal Undang-undang terkait hal tersebut, Jurnal ini bertujuan untuk mengetahui Problematika terkait masalah tindak pidana ITE serta untuk mengetahui upaya-upaya penanganan tindak pidana ITE. Jurnal ini menggunakan metode yuridis normative. Sedangkan analisis dengan metode deskriptif kualitatif. Adapun hasil dari tulisan ini Persoalan cyber crime merupakan persoalan yang sangat kompleks baik terkait dengan masalah hukum, seperti masalah jurisdiksi yaitu Masalah yang berkaitan dengan masalah kekuasaan atau kewenangan, yaitu siapa yang berkuasa/berwenang mengatur dunia internet, Persoalan lain adalah terkait dengan etika dan moral yang berkaitan dengan nilai yang baik dan buruk dan langkah-langkah yang di tempuh dalam penaggulangan cyber crime adalah fokus pada substansi yaitu masalah peraturan yakni harmonisasi aturan perundangan diberbagai negara, masalah struktur dimana negara harus pro-aktif misalnya menghadiri forum-forum internasioanal terkait dengan cyber crime, memberi pelatihan-pelatihan pada aparat, dan dari budaya hukum adalah perubahan paradigma terkait $C y b e r$ crime sebagai sebuah Tindak pidana.
\end{abstract}

Kata kunci: Tindak Pidana ITE, Jurisdiksi, Problematika 


\section{LATAR BELAKANG}

Tindak pidana terkait dengan ITE atau cyber crime merupakan salah satu bentuk dimensi baru dari kejahatan masa kini yang sebelumnya tidak kenal berbeda dengn tindak pidana konvensionl yang memang ada aturannya dalam Hukum positif di masing-masing Negara sesuai dengan kedaulatan masing-masing Negara dan diharapkan tindak pidana cyber crime juga mampu diakomodasi dalam hukum positif sehingga tindak pidana ini dapat ditanggulangi dan ditangani.

Hal yang menjadi persolan dalam membahas masalah ini adalah terkadang tindak pidana ini dapat dilakukan dalam lintas negara, olehnya itu hal tersebut mendapat perhatian Internasional dengan diadakannya berbagai pertemuan yang membahas persoalan tersebut, tetapi persoalan yang kemudian muncul adalah karena dibeberapa negara menganggap persolan ini bukan sebagai sebuah tindakan kriminal, sehingga hal tersebut menjadi persolan yang kompleks.

Dalam upaya menanggulangi cyber crime itu, resolusi kongress PBB VIII/1990 mengenai computer related crime mengajukan beberapa kebijakan seperti, menghimbau negara anggota untuk mengintensifkan upaya penanggulangan penyalahgunaan komputer yang lebih efektiv baik melalui kebijakan penal (baik hukum pidana materil maupun formal), tetapi juga kebijakan non-penal, misalnya dengan melakukan pencegahan dengan melakukan pendekatan techno-prevention, yaitu upaya pencegahan dengan menggunakan teknologi juga dan upaya untuk mengembangkan pengamanan dan perlindungan komputer. ${ }^{1}$

Persoalan ITE ini bagaikan dua sisi mata uang, disatu sisi memilki manfaat yang sangat besar bagi kehidupan manusia, tetapi disisi lain juga mendatangkan manfaat yang negatif, misalnya masalah Cyber crime merupakan salahsatu sisi gelap dari kemajuan teknologi yang mempunyai dampak negatif sangat luas bagi seluruh kehidupan umat manusia, dimana pemanfaatan ITE tanpa adanya pertimbangan moral serta etika akan membuat manusia akan melakukan tindakan-tindakan negatif yang jauh dari nilai-nilai kemanusiaan, berdasarkan hal tersebut diatas maka persoalan yang penulis angkat dalam tulisan ini adalah problematika persoalan ITE dalam kehidupan serta upaya-upaya yang ditempuh dalam penanganan masalah ITE.

\footnotetext{
1 Barda Nawawi, Tindak pidana Mayantara, cetakan pertama (Jakarta: Raja Grafindo Persada, 2006) hlm. 6.
} 


\section{METODE PENULISAN}

\section{Tipe Penelitian}

Dalam penelitian ini penulis menggunakan jenis penelitian hukum normatif, yaitu suatu prosedur penelitian ilmiah untuk menemukan kebenaran berdasarkan logika keilmuan hukum dari sisi normatif. ${ }^{2}$ Terutama yang berkaitan dengan masalah cyber crime, masalah Undang-undang ITE

\section{Jenis dan Sumber Data}

Sumber data dalam tulisan ini bersumber dari data sekunder yakni data yang tidak bersumber dari orang tapi dari data-data, buku dan menggunakan bahan hukum primer yakni dari peraturan perundangan-undangan; lalu kedua bahan Hukum Sekunder adalah data yang diperoleh dari hasil studi dokumendokumen, literature maupun sumber bacaan lainnya yang dipandang relevan dengan penulisan; dan ketiga Bahan hukum tersier yang memberikan informasi tentang bahan hukum primer dan bahan hukum sekunder.

\section{Teknik Pengumpulan Data}

Untuk mendapatkan data sebagai bahan penelitian ini, penulis menggunakan teknik pengumpulan data melalui cara:

Studi Kepustakaan, Merupakan tehnik pengumpulan data sekunder yakni sumber dta bukan dari orang secara

2 Johnny Ibrahim, Teori \& Metodologi Penelitian Hukum Normatif, (Malang: Bayumedia Publishing), hlm. 57. langsung tapi data-data atau dari bahan Hukum primer semisal peraturan perundang-undangan,buku-buku,dokumendokumen dan bahan pustaka atau bahan tertulis lainnya yang berhubungan dengan suatu peristiwa atau aktifitas tertentu yang berkaitan dengan perumusan masalah dalam penelitian yang akan dijawab.

\section{Teknik Analisa Data}

Dalam menganalisis data maka peneliti menggunakan cara deskriptif kualitatif, dengan metode deduktif yakni menggunakan teori yaitu untuk memperoleh gambaran umum yang menyeluruh dan sistematis terkait masalah tindak pidana ITE atau cyber crime.

\section{PEMBAHASAN}

\section{Problematika ITE dalam kehidupan}

Persoalan ITE bagaikan dua sisi mata uang, disatu sisi memberikan manfaat yang besar dalam kehidupan umat manusia, sehingga tidak ada lagi sekat-sekat untuk mengetahui informasi dibelahan bumi lain dan ada banyak lagi keuntungankeuntungan terkait dengan adanya teknologi seperti itu itu, tetapi disisi lain persolan teknologi ini juga mempunyai dampak yang negatif dan bahkan pada derajat tertentu membuat manusia menjadi budak dari teknologi, sehingga melakukan hal-hal yang negatif, maka akan timbul penilaian secara moral dan etika. 


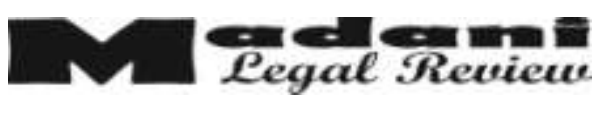

Terkait dengan masalah teknologi ini ada banyak problem yang terjadi, olehnya itu penulis akan mengkaji dari berbagai aspek secara umum atau dalam konteks umum yaitu terkait dengan masalah hukum serta persoalan moral dan etika, terkait dengan persoalan hukum ada beberapa problem yang terjadi seperti:

\subsection{Persoalan jurisdiksi}

Masalah jurisdiksi pada hakikatnya berkaitan dengan masalah kekuasaan atau kewenangan, yaitu siapa yang berkuasa/ berwenang mengatur dunia internet, terkait dengan ini menurut David R. Johnson dan david g. Post mengemukakan model-model yaitu pelaksanaan kontrol dilakukan oleh badan-badan pengandilan yang saat ini ada, penguasaan nasional melakukan kesepakatan internasional mengenai the goverment of cyber space, pembentukan suatu organisasi internasioanal baru yang secara khusus menangani masalah-masalah di dunia internet dan terakhir pemerintah/ pengatur sendiri (self governence) oleh para pengguna internet.

Masaki Hamano dalam tulisannya berjudul comparative study in the approach to jurisdiction in cyber space, mengemukakan adanya jurisdiksi yang didasarkan pada prinsip-prinsip tradisional, seperti jurisdiksi legislatif, yudisial dan jurisdiksi eksekutif, Persoalan diatas menimbulkan diskusi yang panjang terkait dengan masalah jurisdiksi, ada beberapa ahli yang sepakat dengan model pemerintah/ pengatur sendiri (self governance) oleh pengguna internet dan berpendapat bahwa penerapan prinsipprinsip tradisioanal dari due process and personal jurisdiction tidak sesuai dan mengacaukan apabila diterapkan cyber space, maka cyber space arus diperlakukan sebagai suatu ruang yang terpisah dari dunia nyata dengan menerapkan hukum yang berbeda untuk cyber space.

Pandangan diatas ditentang oleh beberapa ahli juga, memang disadari bahwa sistem hukum dan jurisdiksi nasional memang mempunyai keterbatasan karena tidaklah mudah menjangkau pelaku tindak pidana diruang cyber, namun tidak berarti dibiarkan bebas tanpa hukum, namun kewenangan suatu negara dibidang jurisdiksi legislatif ini bisa berbeda dan bahkan berbenturan dengan kewenangan negara lain yang mungkin tidak mengkriminalisasikannya, ini yang menjadi persoalan di bidang jurisdiksi.

Menurut Barbara Etter, ada beberapa persoalan pokok terkait dengan masalah jurisdiksi dalam konteks internasional antara lain, pertama tidak adanya konsensus global mengenai jenisjenisnya, kurangnya keahlian aparat penegak hukum dan ketidakcukupan 
hukum untuk melakukan investigasi dan mengakses sistem komputer, adanya sifat transnasional dari computer crime, ketidakharmonisan hukum acara diberbagdan yang terakhir adalah kurangnya sinkronisasi mekanisme penegakan hukum, bantuan hukum, ekstradisi dan kerjasama internasional dalam melakukan investigasi cyber crime. ${ }^{3}$

\subsection{Persoalan etika dan moral}

Persoalan ITE sebagaimana dikemukakan diatas merupakan dua sisi mata uang, disatu sisi membawa manfaat yang besara bagi kehidupan umat manusia, tetapi juga memiliki sisi negatif yang biasanya dimanfaatkan oleh oknum-oknum tertentu untuk melakukan tindakantindakan negatif, karena sifatnya yang tidak mengenal ruang dan waktu, tanpa menguras energi serta sifatnya yang aman karena bisa dilakukan di manapun ,bahkan dari gubuk kecil sekalipun, ini tentunya dilakukan tanpa pertimbangan moral dan etika.

Persoalan etika merupakan bagian dari teori nilai, dimana teori nilai merupakan salahsatu dari teori filsafat, disamping teori pengetahuan dan teori hakikat, etika membicarakan tentang baik dan buruk perbuatan manusia dengan fokus

\footnotetext{
${ }^{3}$ Ibid., hlm. 6.
}

kajian tentang nilai-nilai ${ }^{4}$, persoalan etika biasanya dipersandingkan dengan masalah moral yang juga berkaitan dengan nilai yang baik dan buruk, sekalipun keduanya sulit untuk dipisahkan tetapi persoalan etika sifatnya tidak spontan yang mana memerlukan penalaran, mengumpulkan informasi, menguji validitas norma, kritis, serta berpedoman pada metode dalam mengambil keputusan etis, jadi sifatnya lebih kompleks jika dibanding dengan persoalan moral. ${ }^{5}$

Menurut Frans Magnis Suseno dalam buku dasar-dasar etika disebutkan bahwa ajaran tentang baik dan buruk itu adalah masalah moral, ada banyak ajaran-ajaran diluar diri manusia salah satunya adalah ajaran moral olehnya itu dibutuhkan etika untuk mengkritisi ajaran moral sehingga dapat dipilih ajaran moral yang tepat. ${ }^{6}$

Menurut penulis terkait dengan masalah etika dan moral dan berkaitan dengan pengertian para pakar diatas bahwa jika masalah moral dan etika itu adalah persolan baik dan buruk tetapi etika itu adalah bagian terdalam dari moral, sebagaimana di bahasakan oleh Frans

\footnotetext{
${ }^{4}$ H.Juhaya S.Praja, Teori hukum dan aplikasinya, (Bandung:Pustaka setia, 2011) hlm. 2.

5 Berbard 1.Tanya, Penegakan Hukum Dalam terang Etika, (Yogyakarta: Genta Publishing,2011) hlm.1-2.

${ }^{6}$ Frans Magnis Suseno, Etika dasar, masalahmasalah Pokok Filsafat Moral, (Yogyakarta: PT Kanisius,2017) hlm. 14.
} 
Magnis Suseno bahwa fungsi etika adalah mengkritisi ajaran-ajaran yang bersala dari luar etika, semisal ajaran moral, agama , dll.

Dikaitkan dengan masalah ITE maka ada berapa konsep terkait dengan moral dan etika yaitu: yang pertama adalah persoalan moral dan etika dari persfektif internal, dimana persoalan moral dan etika ini adalah merupakan sistem nilai tentang baik dan buruk, dimana pada tataran ini etika sebagai pengontrol bagi diri untuk tidak melakukan tindakan-tindakan yang tidak bermoral, apalagi jika dikaitkan dengan persoalan ITE, hal tersebut sangat penting sebagai upaya penanggulangan dari penyalahgunaan ITE, dimana langkah yang tepat adalah kembali kepada diri pribadi yang harus memiliki nilai-nilai etika.

Kedua, adalah persoalan moral dan etika dari persfektif eksternal, sebagaimana disebutkan diatas bahwa persoalan moral dan etika sulit untuk dipisahkan apalagi jika dipahami secara internal, tetapi untuk membedakannya dari perspektif eksternal terlihat dari sifatnya memberikan sebuah penilaian, bahwa moral sifatnya spontan, misalnya dalam persoalan ITE ada seseorang yang melakukan perbuatan yang secara lahiriah dianggap negatif, karena sifatnya spontan maka pelaku tersebut langsung dicap tidak bermoral, berbeda dengan konsep etika yang sifatnya tidak spontan yang mana memerlukan penalaran, mengumpulkan informasi, menguji validitas norma, kritis, serta berpedoman pada metode dalam mengambil keputusan etis, jadi sifatnya lebih kompleks jika dibanding dengan persoalan moral, sebagaimana contoh diatas dalam persfektif etika hal tersebut harus butuh analisis, apa motif atau faktor-faktor penyebab seseorang melakukan hal yang negatif, setelah proses dianalisis kemudian ditarik sebuah kesimpulan apakah itu etis atau tidak.

Ketiga, persoalan etika dan moral dari persfektif yang lain bahwa etika itu adalah bagian yang paling terdalam pada diri manusia yang mampu mengkritisi ajaran-ajaran yang bersumber dari luar diri manusia salahsatunya adalah masalah ajaran moral, jika dikaitkan dengan masalah ITE atau tindak pidana cyber crime, maka yang paling dibutuhkan antara moral dan etika ketika berhadapan dengan teknologi adalah persolaan etika dimana persolaan etika akan menjadi jernih, akan menjadi pilihan yang tepat ketika juga dilandasi oleh nilai-nilai agama, hal ini dapat tergambarkan seperti kaca yang bening, ketika kaca itu bening maka pilihan-pilihan akan tepat, begitu pula sebaliknya ketika kaca yang menjadi suara 
hati itu buram, maka pilihan-pilihan itu biasanya tidak tepat.

Dalam konteks agama hala-hal yang buram itu adalah dosa-dosa yang dilakukan, olehnya itu dosa-dosa itu harus dimohonkan ampunan kepada pencipta sehingga kaca itu (suara hati ) bening dan berdampak pada pilihan yang tepat.

\section{Usaha-usaha yang ditempuh dalam penanganan Masalah ITE}

Dalam konteks Indonesia, menurut penulis untuk menjawab usaha yang ditempuh dalam menghadapi persoalan ITE, maka penulis menggunkan teori sistem hukum dari L.Friedman, bahwa ada tiga hal yang mesti dibenahi yaitu, substansi hukum (materi) atau (legal substance), struktur hukum (legal structure), dan budaya hukum (legal culture).

Sedangkan menurut L.M Friedman bahwa substansi hukum adalah aturan, norma dan pola prilaku nyata manusia yang berada dalam sistim itu, struktur hukum berkaitan dengan hal penegakan hukum (law enforcement), yakni bagaimana substansi hukum ditegakkan. Struktur hukum juga berkaitan dengan sistem peradilan yang berhubungan langsung dengan sumber daya manusia bidang hukum yang terdiri dari hakim, jaksa, polisi, pengacara, pejabat lembaga pemasyarakatan, termasuk susunan kelembagaan dan yurisdiknya.

Sedangkan budaya hukum diibaratkan sebagai a working machine sistem hukum atau merupakan the element of social attitude and value. Jadi budaya hukum berkaitan dengan sikap budaya masyarakat pada umumnya, karena menyentuh keyakinan (belief), nilai (value), cita (idea), dan harapan (expectation) sehingga dapat dikatakan, kesadaran hukum masyarakat merupakan salah satu pencerminan budaya hukum mereka. Budaya hukum ini, menurut Roem Topatimasang dkk. meliputi persepsi, pemahaman, sikap penerimaan, praktikpraktik penerimaan, dan penafsiran terhadap isi dan tata laksana hukum.

Selain itu menurut Friedman legal behaivior ( budaya hukum) adalah

"Perilaku yang dipengaruhi oleh aturan, keputusan, perintah, atau Undang-Undang yang dikeluarkan oleh pejabat dengan wewenang hukum. Jika saya berprilaku secara khusus karena diperintahkan hukum atau karena tindakan pemerintah , atau amanat atau perintah dari pemerintah atau dari sistim hukum atau daru pejabat didalamnya, inilah perilaku hukum. Jika saya berkendaraan di sepanjang jalan dan melihat rambu batas kecepatan ( atau melihat polisi) dan memperlambat kendaraan, ini adalah perilaku hukum."7

\footnotetext{
${ }^{7}$ L.W. Friedman, American law: an intruduction, dalam Achmad Ali, Menguak teori hukum dan teori
} 
Berdasarkan hal tersebut penulis mengidentifikasi bahwa ada tiga hal yang mesti diubah sesuai dengan teori L.Friedman yakni:

\subsection{Masalah Substansi}

Mengutip pandangan Djalal Abubakar seorang guru besar pada Program Pasca Sarjana Universitas Hasanuddin menjelaskan bahwa substansi hukum ini tidak hanya menyangkut kaidah tertulis (written law) yang lazim disebut peraturan perundang-undangan tetapi juga termasuk kaidah hukum yang tidak tertulis (unwritten law), termasuk dalam substansi hukum adalah keluaran sistem hukum itu sendiri, seperti jurisprudensi, keputusan dan sebagainya.

Sedangkan menurut L.M Friedman bahwa substansi hukum adalah aturan, norma dan pola prilaku nyata manusia yang berada dalam sistim itu, olehnya itu penulis juga mengkaji substansi hukum, apakah tindakan yang dilakukan polisi sudah sesuai dengan substansi yang tentunya akan berkaitan dengan budaya hukum, dimana tindakan hukum adalah perilaku apa pun yang dilakukan oleh siapa

peradilan, (Jakarta:Prenada media grup, 2010), hlm. 143. pun yang memiliki otoritas yang bertindak dalam sistem hukum. ${ }^{8}$

Adapun yang harus dibenahi dalam hal substansi ini adalah masalah aturan yang terkait dengan masalah teknologi secara global persoalan substansi ini telah disebutkan dalam resolusi kongres PBB VIII/ 1990 mengenai computer related crimes denganbeberapa kebijakan yaitu melakukan medernisasi hukum pidana baik pidana materil dan hukum acara pidana ${ }^{9}$, selain hal tersebut diatas juga yang diperlukan adalah melakukan kriminalisasi, dimana kebijakan ini menetapkan suatu perbuatan yang semula bukan tindak pidana menjadi suatu tindak pidana dimana harus ada harmonisasi ketentuan-ketentuan yang berhubungan dangan kriminalisasi, pembuktian, dan prosedur, jadi masalahnya bukan sekedar persoalan kebijakan hukum pidana, tetapi bagaimana melakukan harmonisasi kebijakan di bidang penanggulangan, tetapi bagaimana ada harmonisasi kebijakan penal di berbagai negara. ${ }^{10}$

Terkait dengan masalah ini harus ada harmonisasi peraturan yang mengatur masalah cyber crime, sehingga dalam hal

\footnotetext{
8 L.M Friedman, The legal system: A Social Science Perspective, Terjemahan, M.khozim, Sistem hukum: Perspektif sosial, (Bandung: Nusa Media, 2011) hlm. 80-81.

${ }^{9}$ Nawawi., op., cit., hlm. 2.

${ }^{10}$ Ibid., hlm. 90-91.
} 


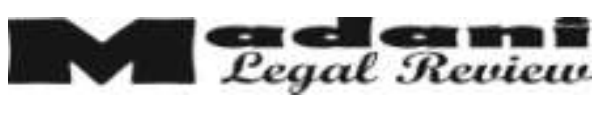

penanganannya bisa lebih efektif karena tindak pidana ITE atau cyber crime ini dapat dilakukan lintas daerah tanpa ada sekat-sekat, olehnya itu dalam penanganannya juga harus melibatkan beberapa negara dan yang menjadi persoalan adalah ketika disuatu negara persoalan ITE bukan merupakan tindak pidana maka hal ini sulit ditangani.

Dalam konteks Indonesia aturan terkait dengan ITE belum lengkap, khususnya dalam hal pemidanaan, misalnya pidana kerja sosial, dimana pidana yang dikenakan kepada terpidana bukan lagi penjara tetapi melakukan kerja sosial, sejarah pidana kerja sosial telah lama diterapkan dinegara-negara Eropa dan hal yang juga menjadi perhatian dalam penerapan kerja sosial adalah landasan filosofi setiap negara berbeda terutama terkait dengan masalah pemidanaan.

Hal tersebut diatas harus menjadi perhatian, karena persoalan pemidanaan merupakan hal yang substansial karena akan berkaitan dengan hak asasi manusia yakni terkait dengan perampasan kemerdekaan dan itu diperdebatkan oleh beberapa ahli, menurut Muladi yang terpenting dalam hal ini adalah bagaimana penggunaan pidana perampasan kemerdekaan dapat dibatasi terutama pidana perampasan kemerdekaan jangka pendek. $^{11}$

Sudah saatnya harus ada pembaharuan dalam hukum pidana Indonesia untuk mengakomodasi persoalan pidana kerja sosial sebagai alternatif dalam pemidanaan terkait dengan ITE, hal pertama yang harus dilakukan adalah pemahaman filosofi yakni landasan ontologinya yaitu harus dipahami secara lebih komperhensif persoalan cyber crime, misalnya dalam hal kriminalisasi, sampai pada persoalan pemidanaan (kerja sosial).

Persoalan filosofi merupakan hal yang urgent dalam penetapan kerja sosial, dimana secara filosofi kita merujuk pada pancasila yang memuat nilai-nilai, seperti nilai Ketuhanan, kemanusian, persatuan, musyawarah/demokrasi, serta nilai-nilai keadilan, hal ini semua yang harus menjadi landasan dalam penetapan kerja sosial sebagai alternatif pemidanaa. Pidana kerja sosial selaras dengan sila kelima pancasila yaitu keadilan sisoal bagi seluruh rakyat Indonesia yang didalamnya terkandung nilai kerja keras yang merupakan sarana untuk menuju keadilan sosial, selain itu juga sesuai dengan sila ke-2 dimana terkandung nilai-nilai pengakuan terhadap martabat manusia, dimana manusia

\footnotetext{
11 Tongat, Pidana kerja sosial dalam pembahruan hukum pidana Indonesia, (Jakarta:Djambatan, 2001) hlm. 15.
} 
dituntut berlaku adil dan menghormati hak asasi manusia lainnya dan hal ini tampak dari terpidana yang ditempatkan di tempat kerja sesuai dengan keterampilan dan bakat narapidana, tidak merampas kemerdekaan narapidana dan dibimbing ke jalan yang lebih benar oleh petugas yang berkompoten. ${ }^{12}$

Selain landasan filosofi diatas, secara teoritis pidana kerja sosial juga sesuai dengan tujuan pemidanaan yang integratif yakni memberikan perlindungan terhadap masyarakat, dimana penjatuhan pidana kerja sosial, masyarakat terlindungi dari pengulangan tindak pidana, sebagai pemelihara solidaritas masyarakat, dimana melalui kerja sosial masyarakat mengetahui bahwa terpidana sudah dijatuhi hukuman sehingga memperkecil atau bahkan meniadakan kemungkinan balas dendam. ${ }^{13}$

Hal yang menjadi penting juga adalah kerja sosial yang nanti dilakukan oleh para nara pidana harus sesuai dengan bidang kejahatanya misalnya persoalan ITE kerja sosialnya dibidang ITE, misalanya rata-rata pelaku cyber crime mempunyai pendidikan tinggi, kemampuan mereka sangat memadai dalam mengoperasikan komputer beserta sistem

\footnotetext{
${ }^{12}$ Widodo, sistem pemidanaan dalam cyber crime, (Yogyakarta:Laksbang Mediatama, 2009) hlm. 183.

${ }^{13}$ Ibid., hlm. 190.
}

aplikasinya, ulet, kreatif. Jika kemampuan terpidana tersebut, misalnya teknik pengamanan program atau sistem diajarkan kepada masyarakat atau institusi tempat pelaksanaan pidana kerja sosial maka perkembangan teknologi informasi dapat lebih cepat dan aman. ${ }^{14}$

Selain itu yang menjadi perhatian juga dalam penetapan kerja sosial adalah persoalan gradasi, dimana pidana sosial hanya dapat diterapkan terhadap tindak pidana yang tidak terlalu berat atau dengan kata lain tidak dijatuhkan untuk tindak pidana yang berat, untuk konteks Indonesia berdasarkan ketentuan pasal 52 KUHP majelis hakim sepakat untuk pidana kerja sosial diberlakukan terhada terpidana yang tidak melebihi 6 bulan, selain itu berkaiatan juga dengan usia pelaku, misalnya di bawah umur tidak dikenakan pidana kerja sosial, dan juga harus diperhatikan jam kerja, berkaitan dengan ketentuan minimum pidana kerja sosial dibebarapa negara terdapat perbedaan, di Portugal dilakukan dalam waktu 9 jam, di Denmark, Prancis, Inggris minimum 40 jam, ${ }^{15}$ Untuk konteks Indonesia sesuai undang-undang Ketenagakerjaan maka batas minimun adalah 8 jam kerja, olehnya itu terkait dengan pidana kerja sosial ini sudah seharusnya diakomodasi dalam

\footnotetext{
${ }^{14}$ Ibid., hlm. 156.

${ }^{15}$ Ibid., hlm. 11.
} 
Undang-undang sebagai alternatif pemidanaan.

Undang-undang yang dibentuk nantinya adalah Undang-undang yang memenuhi kriteria "acceptable" yaitu dari substansinya produk hukum itu memang dibutuhkan dan dapat diterima masyarakat, "aplicable" yaitu Undang-Undang itu secara keseluruhan dari pasal-pasalnya termasuk penjelasannya harus dapat dilaksanakan dalam praktek penyelenggaraan kehidupan bermasyarakat serta harus "visible" bahwa produk hukum yang dihasilkan harus mampu menjangkau tuntutan kebutuhan kedepan dalam jangka waktu yang lama sehingga terhindar dari permasalahan-permasalahan implementatif yang muncul dalam waktu singkat setelah berlakunya suatu Undang-Undang. ${ }^{16}$

\subsection{Struktur}

Struktur hukum berkaitan dengan hal penegakan hukum (law enforcement), yakni bagaimana substansi hukum ditegakkan. Struktur hukum juga berkaitan dengan sistem peradilan yang berhubungan langsung dengan sumber daya manusia bidang hukum yang terdiri dari hakim, jaksa, polisi, pengacara, pejabat lembaga

\footnotetext{
${ }^{16}$ Darmono, Kuliah Umum Pasca Sarjana UII, hari sabtu tanggal 21 september 2013 di Yogyakarta, Lt.3 Pasca sarjana UII.
}

pemasyarakatan, termasuk susunan kelembagaan dan yurisdiknya. ${ }^{17}$

Berkaitan dengan masalah struktur yang harus dilakukan sebagaimana dalam kongres PBB VIII/1990 adalah Negaranegara anggota harus melakukan upayaupaya seperti mengembangkan tindakantindakan pencegahan dan pengamanan komputer, melakukan langkah-langkah untuk membuat peka warga masyarakat, aparat pengadilan dan penegak hukum, terhadap pentingnya pencegahan kejahatan yang berhubungan dengan komputer, melakukan upaya-upaya pelatihan bagi para hakim, pejabat dan aparat penegak hukum mengenai kejahatan cyber crime, mengadopsi kebijakan perlindungan korban CC sesuai dengan deklarasi PBB mengenai korban dan mengambil langkahlangkah untuk mendorong korban melapokan adanya $\mathrm{CC}$, meningkatkan kegiatan-kegiatan internasional dalam upaya penanggulangan cyber crime. ${ }^{18}$

Hal lain yang berkaitn dengan struktur adalah peningkatan kapasitas aparat penegak hukum berkaitan dengan masalah cyber crime, atau tindak pidana di dunia maya, dalam hal ini bisa dilakukan dengan pemanfaatan para hecker untuk tindakan-tindakan positif seperti pencegahan tindak pidana di dunia maya

\footnotetext{
17 Ali, loc.cit.

${ }^{18}$ Nawawi, op.,cit., hlm.3-4.
} 


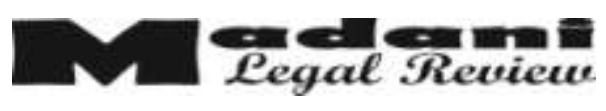

atau tujuan lain untuk mengumplkan buktibuti terkait masalah tindak pidana dunia maya. Dan yang terpenting tentunya adalah political will dari penguasa untuk mencegah terjadinya tindak pidana didunia maya.

\subsection{Culture/Budaya Hukum}

Budaya hukum diibaratkan sebagai $a$ working machine sistem hukum atau merupakan the element of social attitude and value. Jadi budaya hukum berkaitan dengan sikap budaya masyarakat pada umumnya, karena menyentuh keyakinan (belief), nilai (value), cita (idea), dan harapan (expectation) sehingga dapat dikatakan, kesadaran hukum masyarakat merupakan salah satu pencerminan budaya hukum mereka. ${ }^{19}$ Pengertian Budaya yang lain menurut Roem Topatisomang dkk, meliputi persepsi, pemahman, sikap penerimaan, praktik-praktik dan penafsiran terhadap isi dan tata laksana Hukum ${ }^{20}$

Selain itu menurut Friedman legal behaivior ( budaya hukum) adalah

"Perilaku yang dipengaruhi oleh aturan, keputusan, perintah, atau Undang-Undang yang dikeluarkan oleh pejabat dengan wewenang hukum. Jika saya berprilaku secara khusus karena diperintahkan hukum atau karena tindakan pemerintah, atau

\footnotetext{
${ }^{19}$ Ibid., hlm. 148.

${ }^{20}$ Rusdin Tompo, Ayo Lawan Korupsi (Makassar:LBH-P21, 2005) hlm. 44.
}

amanat atau perintah dari pemerintah atau dari sistim hukum atau daru pejabat didalamnya, inilah perilaku hukum. Jika saya berkendaraan di sepanjang jalan dan melihat rambu batas kecepatan ( atau melihat polisi) dan memperlambat kendaraan, ini adalah perilaku hukum."

Terkait dengan istilah budaya,dalam kamus besar Bahasa Indonesia diartikan sebagai 1) pikiran;akal budi:hasil budaya; 2) adat istiadat:menyelidiki bahasa dan budaya; 3) sesuatu mengenai kebudayaan yang sudah berkembang (beradab, maju): jiwa yang budaya; 4) sesuatu yang sudah menjadi kebiasaan yang sukar diubah. ${ }^{21}$

Budaya atau kebudayaan berasal dari bahasa Sanskerta yaitu buddhayah, yang merupakan bentuk jamak dari buddhi (budi atau akal) diartikan sebagai hal-hal yang berkaitan dengan budi dan akal manusia. Dalam bahasa Inggris, kebudayaan disebut culture, yang berasal dari kata Latin Colere, yaitu mengolah atau mengerjakan. Bisa diartikan juga sebagai mengolah tanah atau bertani. Kata culture juga kadang diterjemahkan sebagai "kultur" dalam bahasa Indonesia.

Budaya adalah suatu cara hidup yang berkembang dan dimiliki bersama oleh sebuah kelompok orang dan diwariskan

\footnotetext{
${ }^{21}$ Budiono Kusumohamidjojo, Filsafat Kebudayaan proses realisasi manusia, (Yogyakata:Jalasutra, 2010) hlm. 35-35.
} 


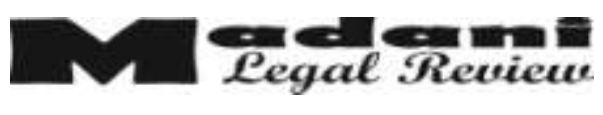

dari generasi ke generasi. Budaya terbentuk dari banyak unsur yang rumit, termasuk sistem agama dan politik, adat istiadat, bahasa, perkakas, pakaian, bangunan, dan karya seni. Bahasa, sebagaimana juga budaya, merupakan bagian tak terpisahkan dari diri manusia sehingga banyak orang cenderung menganggapnya diwariskan secara genetis. Ketika seseorang berusaha berkomunikasi dengan orang-orang yang berbeda budaya dan menyesuaikan perbedaanperbedaannya, membuktikan bahwa budaya itu dipelajari.

Budaya adalah suatu pola hidup menyeluruh. budaya bersifat kompleks, abstrak, dan luas. Banyak aspek budaya turut menentukan perilaku komunikatif. Unsur-unsur sosio-budaya ini tersebar dan meliputi banyak kegiatan sosial manusia, Beberapa alasan mengapa orang mengalami kesulitan ketika berkomunikasi dengan orang dari budaya lain terlihat dalam definisi budaya:

"Budaya adalah suatu perangkat rumit nilai-nilai yang dipolarisasikan oleh suatu citra yang mengandung pandangan atas keistimewaannya sendiri."Citra yang memaksa" itu mengambil bentuk-bentuk berbeda dalam berbagai budaya seperti "individualisme kasar" di Amerika, "keselarasan individu dengan alam" di Jepang dan "kepatuhan kolektif" di Cina."

Citra budaya yang bersifat memaksa tersebut membekali anggota-anggotanya dengan pedoman mengenai perilaku yang layak dan menetapkan dunia makna dan nilai logis yang dapat dipinjam anggotaanggotanya yang paling bersahaja untuk memperoleh rasa bermartabat dan pertalian dengan hidup mereka. Dengan demikian, budayalah yang menyediakan suatu kerangka yang koheren untuk mengorganisasikan aktivitas seseorang dan memungkinkannya meramalkan perilaku orang lain. $^{22}$

Dikaitkan dengan hukum, maka budaya hukum adalah tanggapan umum yang sama dari masyarakat tertentu terhadap gejala-gejala hukum. Tanggapan itu merupakan kesatuan pandangan terhadap nilai-nilai dan perilaku hukum. Jadi suatu budaya hukum menunjukkan tentang pola perilaku individu sebagai anggota masyarakat yang menggambarkan tanggapan (orientasi) yang sama terhadap kehidupan hukum yang dihayati masyarakat bersangkutan.

Lawrence M. Friedman mengemukakan bahwa kita telah menghabiskan banyak waktu membicarakan aturan hukum dan struktur hukum yang menciptakan dan melaksanakan aturan itu, namun sekali lagi harus ditegaskan bahwa sistim hukum lebih dari dari struktur dan aturan, meski demikian aturan harus diikuti setidaknya

22، Budaya "http://id.wikipedia.org/wiki/budaya, diakses 22 februari 2014 


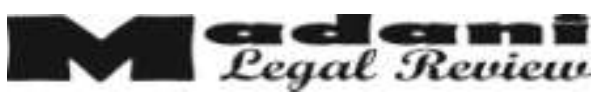

pada masanya. Perilaku merupakan unsur pokok sistim hukum, apa yang sesungguhnya dijalankan orang, jika tidak dijalankan aturan itu hanya tulisan belaka dan struktur itu seperti kota mati, bukan kota hidup. Tidak ada cara lain untuk memahami sistim hukum termasuk hukum kita sendiri selain melihat perilaku hukum (legal behavior).

Dari uraian diatas jelas bahwa yang dimaksud perilaku hukum, bukan hanya perilaku taat hukum, tetapi semua perilaku yang merupakan reaksi terhadap sesuatu yang sedang terjadi dalam sistem hukum, baik reaksi ketaatan pada hukum maupun ketidaktaatan pada hukum dan dapat disimpulkan bahwa perilaku hukum meliputi perbuatan hukum (rechtshandeling) yaitu perbuatan yang dilakukan oleh subjek hukum, yang mempunyai akibat hukum memang dikehendaki oleh si pelaku dan perbuatan melawan hukum (onrechhtmatige daad) yaitu perbuatan yang dilakukan oleh subjek hukum yang mempunyai akibat hukum, dimana akibat hukumnya tidak dikehendaki oleh si pelaku baik dalam bidang perdata atau dalam bidang pidana.

Selain itu dari segi normatif perbuatan hukum masih dibedakan yakni perbuatan hukum bersegi satu (eenzidige rechthandeling), dimana akibat hukumnya timbul dengan adanya pernyataan kehendak dari satu pihak saja dan perbuatan hukum bersegi dua (tweezijdige rechthandeling), yaitu akibat hukumnya timbul karena pernyataan kehendak dari dua pihak atau lebih seperti perjanjian dan gesamtakt, yang merupakan tindakan bersama yang bukan perjanjiaan, karena tanpa pernyataan kehendak yang dilahirkan yang bergantung satu sama lain dan dan menimbulakan akibat hukum untuk kepentingan subjek hukum yang menyatakan kehendaknya, atas beban subjek hukum lainya.

Lawrence M. Friedman menguraikan juga tentang bagaimana mempengaruhi perilaku hukum, yaitu yang pertama komunikasi hukum (communication of the law), bagaimanakah aturan ini dikomunikasikan, ada aturan yang sebenarnya menjadi pengetahuan umum. Sebagian besar aturan dan tentunya semua aturan yang teknis, aturan administratif yang diperinci harus disampaikan secara khusus kepada audiensnya, yang kedua adalah pengetahuan hukum (knowledge of law) dimana pengetahuan hukum sebagai faktor esensial perilaku hukum, seberapa banyak kemampuan seseorang memahami tentang sebuah aturan hukum yang tentunya akan berpengaruh terhadap perilaku atau budaya hukum. ${ }^{23}$

${ }^{23}$ Ali, op. cit., hlm. 143-165. 


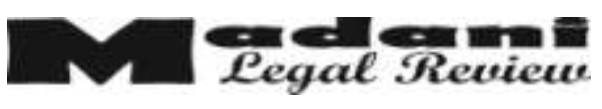

Komunikasi memang vital artinya bagi dampak, tetapi komunikasi hanya merupakan prasyarat; komunikasi tidak bisa menjelaskan bagaimana dan mengapa orang-orang yang menerima pesan itu bertindak. Ada dua jenis komunikasi organisasi yakni komunikasi vertikal baik komunikasi dari atas ke bawah atau dari bawah ke atas dan komunikasi horisontal yakni komunikasi mendatar antar personil. ${ }^{24} \mathrm{dan} \quad$ komunikasi akan tersampaikan dengan baik manakala komunikatornya memenuhi syarat seperti, memiki kredibilitas (terpercaya), objektivitas (melihat seluruh sisi masalah) dan keahlian ( pakar dan memenuhi kualifikasi). ${ }^{25}$ Dan apabila sebuah kekuasaan menghendaki suatu bentuk tindakan komunikatif, maka penguasa harus mengadopsi ideologi terbuka, dengan demikian kekuasaan yang terbangun adalah kekuasaan yang berpondasi relasi yang baik antara anggotanya menjadi kehidupan yang berkualitas, dimana kekuasaan adalah milik bersama dan bukan milik induvidu. ${ }^{26}$

Dalam Konteks ini budaya hukum yang terpenting adalah perubahan

\footnotetext{
${ }^{24}$ Suwarni, Reformasi Ke-Polisian, (Yogyakarta: UII Press, 2010) hlm. 38.

25 Alo Liliweri, Dasar-dasar komunikasi antar Budaya, (Yogyakarta:Pustaka Pelajar, 2009) hlm. 91.

${ }^{26}$ Rieke Diah Pitaloka, Kekerasan negara menular ke Masyarakat, (Yogyakarta:Galangpress, 2004) hlm. 183-184.
}

paradigma bahwa tindak pidana tidak hanya terjadi secara konvensional tetapi juga dalam bentuk yang lebih canggih, sehingga dapat di tempuh langkah yang tepat dalam penaggulangannya, selanjutnya adalah merubah paradigma ekonomi yang sifatnya umum bukan hanya berkaitan dengan pengguna, pemilik tapi juga aparat penegak hukum dalam penaggulangan masalah ITE, terkait dengan pengguna atau tersangka, dimana mereka melakukan tindakan-tindakan kriminal salahsatunya adalah motif ekonomi, begitu juga pemilik yang berlomba-lomba menghasilkan produkproduk baru tentunya dengan motif ekonomi, begitu pula dalam hal penanganan selalu dikaitkan dengan motif ekonomi, seperti suap- menyuap.

Hal terpenting berikutnya adalah mengedepankan etika dan moral, dimana moral juga disini juga diartikan dengan nilai baik dan buruk ${ }^{27}$, dimana disebutkan diatas bahwa konsep moral dan etika sangat penting dijadikan pedoman dan pegangan untuk menjadi pengontrol bagi diri untuk tidak melakukan tindakantindakan yang tidak bermoral dan tidak etis, karena tindakan ini dapat dilakukan dimana pun, tanpa mengenal batas dan

27 Sudjito, Hukum dalam pelangi kehidupan, (Yogyakarta: Gadjah Mada University Press, 2012) ,hlm.3. 


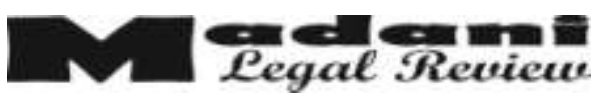

waktu, hal ini lebih diprioritaskan pada pelaku ITE.

\section{KESIMPULAN}

Ada kesimpulan dalam tulisan ini adalah: pertama, Persoalan cyber crime merupakan persoalan yang sangat kompleks baik terkait dengan masalah hukum, seperti masalah jurisdiksi yaitu Masalah yang berkaitan dengan masalah kekuasaan atau kewenangan, yaitu siapa yang berkuasa/berwenang mengatur dunia internet. Kedua, Persoalan lain adalah terkait dengan etika dan moral yang berkaitan dengan nilai yang baik dan buruk.

Ketiga, adapun langkah-langkah yang di tempuh dalam penaggulangan cyber crime adalah fokus pada substansi yaitu masalah peraturan yakni harmonisasi aturan perundangan diberbagai negara, masalah struktur dimana negara harus proaktif misalnya menghadiri forum-forum internasioanal terkait dengan cyber crime, memberi pelatihan-pelatihan pada aparat, dan dari budaya hukum adalah perubahan paradigma terkait $\mathrm{CC}$ sebagai sebuah Tindak pidana.

\section{DAFTAR PUSTAKA}

Ali, Achmad. Menguak teori hukum dan teori peradilan. Jakarta:Prenada media grup, 2010.
Rieke, Diah Pitaloka. Kekerasan negara menular ke Masyarakat. Yogyakarta: Galangpress, 2004.

S.Praja, H.Juhaya. Teori hukum dan aplikasinya. Bandung:Pustaka setia, 2001.

Ibrahim, Johnny. Teori \& Metodologi Penelitian Hukum Normatif. Malang: Bayumedia Publishing.

Liliweri, Alo. Dasar-dasar komunikasi antar Budaya. Yogyakarta:Pustaka Pelajar, 2009.

Friedman, L.M. The legal system: A Social Science Perspective, Terjemahan, M.khozim, Sistem hukum: Perspektif sosial. Bandung: Nusa Media, 2011.

1.Tanya, Berbard. Penegakan Hukum Dalam terang Etika. Yogyakarta: Genta Publishing, 2011.

Magnis Suseno, Frans. Etika dasar, masalah-masalah Pokok Filsafat Moral. Yogyakarta: PT Kanisius, 2017.

Nawawi, Barda, Tindak pidana Mayantara. Jakarta: Raja Grafindo Persada, 2006.

Sudjito, Hukum dalam pelangi kehidupan. Yogyakarta:Gadjah Mada University Press, 2012.

Tongat, Pidana kerja sosial dalam pembahruan hukum pidana Indonesia. Jakarta:Djambatan, 2001.

Tompo, Rusdin. Ayo Lawan Korupsi. Makassar:LBH-P21, 2005.

Widodo, sistem pemidanaan dalam cyber crime. Yogyakarta: Laksbang Mediatama, 2009.

Kusumohamidjojo, Budiono, Filsafat Kebudayaan proses realisasi manusia. Yogyakata:Jalasutra, 2010.

Suwarni, Reformasi Ke-Polisian. Yogyakarta: UII Press, 2010.

Darmono, Kuliah Umum Pasca Sarjana UII, hari sabtu tanggal 21 september 2013 di Yogyakarta, Lt.3 Pasca sarjana UII.

"Budaya"http://id.wikipedia.org/wiki/buda ya, diakses 22 februari 2014. 